\title{
ENHANCEMENT OF WASTE STABILIZATION PONDS EFFICACY USING LOCAL FIXED FILM MATERIALS
}

\author{
R.M. Al-Sa`ed \\ N. Mahmoud \\ A. Abu-Madi \\ O.R. Zimmo \\ Birzeit University, Palestine
}

\begin{abstract}
This paper evaluates the feasibility of using local rock filter as natural media in waste stabilization ponds. A pilot-scale algae-rock filter ponds (ARPs) system was investigated, in parallel with algae-based ponds (ABPs) over a period of 6 months to evaluate the treatment efficacy of both systems. Each system entailed 4 equal ponds in series and was continuously fed with domestic wastewater from Birzeit University. The removal rates of organic matter, nutrients and faecal coliforms were monitored within each treatment system. The results obtained revealed that ARPs system was more efficient in the removal of organic matter (TSS and COD; $86 \%$ and $84 \%$, respectively) and fecal coliforms $\left(4 \log _{10}\right)$ than ABPs $(81 \%, 81 \%, 3$ $\log _{10}$, respectively). Nitrogen was reduced in the ARPs to an average of $24 \mathrm{mg} \mathrm{N} / \mathrm{l}$; in contrast the ABPs effluent contained $32 \mathrm{mg} \mathrm{N} / 1$. Compared to ABP system, passive aerated ARPs option is an efficient, a low-cost and land-saving alternative with effluent quality suitable for restricted agricultural use in rural areas.
\end{abstract}

\section{KEYWORDS:}

Algae-rock filter, domestic wastewater, effluent reuse, removal efficacy

\section{INTRODUCTION}

The prevailing arid and semi arid conditions in Palestine make the reuse of treated and reclaimed effluents for agricultural and industrial purposes imperative to secure economical development and achieve environmental protection. The widening gap between water supply and demand can be reduced effectively with reclaimed domestic and municipal wastewaters. About $17 \%$ of the total domestic and municipal wastewater collected in central sewer networks, experience treatment in onsite and central wastewater treatment plants (WWTPs). However, both onsite and central sewage works are neither operated adequately nor maintained properly, making treated effluent unsuitable for unrestricted agricultural irrigation. As of limited access to freshwater sources, farmers eagerly use both raw and partially treated wastewater for unsustainable irrigation practices [1].

The current onsite wastewater treatment system in Palestinian rural communities were sited and designed commonly based on site specific conditions and funding agencies guidelines with little attention paid to the surrounding environment (soil, surface and groundwater) or the potential of cumulative effects resulting from decentralized wastewater treatment systems. 
The numerous cases of poor treatment performance of onsite systems reported recently highlight the need for upgrading of mismanaged, overloaded and non-functional onsite treatment systems underpinned by solid and reliable scientific knowledge gained from technically and economically feasible process retrofitting approaches [2].

Natural treatment systems as waste stabilization ponds (WSPs) are considered worldwide as a low-cost and appropriate wastewater treatment technique [3-5]. However, major limitations include high effluent concentrations in total suspended solids (TSS) and nitrogen due to large quantities of algal cells and deficiency in nitrification, respectively. The presence of eTSS and nitrogen-rich effluent can restrict effluent reuse in agricultural irrigation, pose public health risks and degrade water quality of receiving water bodies. Nitrogen compounds removal in natural treatment systems is governed by nitrification and denitrification, whilst other mechanisms such as plant uptake and ammonia volatilization are of less importance [6-7]. Improving the WSPs performance for the removal of organic, nitrogen and heavy metal pollutants through the addition of artificial fibrous carriers (attached growth media) in the pond water with different configurations was reported by few pilot-scale studies [8-13]. Laboratory and field research made by Shelton et al., [14] using packed columns biofilters in WSPs revealed that limestone and iron slag as media were effective in phosphorus removal. Also, erection of aerated rock filters [15] were also investigated, however, associated with increased capital and annual running costs [16].

In Germany the layout and design of WSPs [17] is made according to daily surface COD load and require large specific land area between 8 and $10 \mathrm{~m}^{2} /$ capita. In Palestine, limited data are available pertinent to design, operation, and fate of nutrients and microbial pathogens in treated effluent from the current Palestinian onsite treatment systems. However, annual monitoring reports of the Palestinian Water Authority (PWA) into nutrient (nitrate) and microbiological contamination of groundwater and surface water in several districts revealed water quality deterioration [18].

The main aim of this study was to evaluate the effectiveness of algae-rock filter ponds (ARPs) using a natural rock, as a biofilm media, in the removal of organic matter, nutrient, and pathogens from domestic wastewater based on a pilot-scale system. Algae-based ponds (ABPs) were used as a control. The treatment efficacy of both systems is presented related to variable volumetric and hydraulic loads. The effluent guidelines recently adopted by the WHO [19] and the current valid Palestinian Standards [20] were used as a basis for evaluating the suitability of effluent reuse for agricultural purposes.

\section{MATERIALS AND METHODS}

\subsection{Description of the Pilot Plant}

Both pilot scale system; algae-based ponds (ABPs) and algae-rock filter ponds (ARPs) are installed adjacent to the central wastewater treatment plant at Birzeit University campus. Similar to ABPs, the ARPs consisted of 4 subsequent ponds; one anaerobic (AnP), 2 facultative (FP) and one polishing pond (PP), built in concrete with the dimensions of $(\mathrm{LxWxD} ; 3.0 \times 1.0 \times 1.0 \mathrm{~m})$ each, however with rock filter media installed in. The rockbiofilters were immersed in two facultative ponds (ARP1 \& ARP2) to establish the algae-

biofilm media using natural media (locally named as Kharrami stones), where the stones were stocked in low-cost plastic boxes ( 8 boxes each). The rock filter media is locally available at low-cost, and stable with a specific surface area of about $90 \mathrm{~m}^{2}$ per $\mathrm{m}^{3}$. Tow vertical layers of 
four plastic boxes, containing the rock-filters, overlaid above each others, were installed in each side of two facultative ponds (FPs).

The algae-based ponds (ABP) system used in this study has the same layout of the modified one but without having rock-filters. Three wood-made vertical baffles were also installed in co-counter flow mode, which improve the overall mixing pattern. A schematic flow diagram of the two pilot-scale plants (ABPs \& ARPs) is shown in Figure 1.

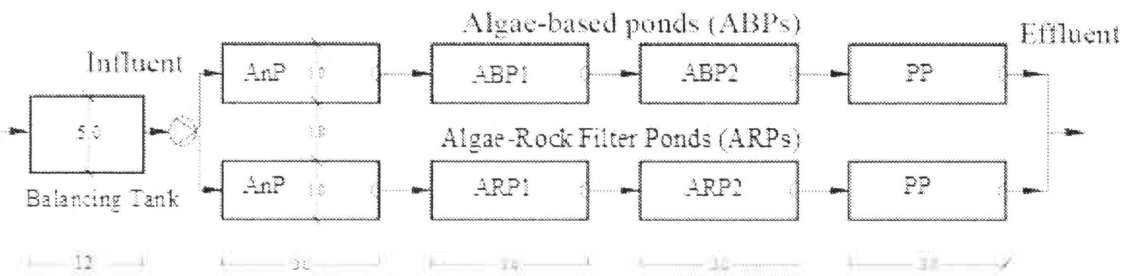

Figure. 1. Schematic flow diagram of the pilot-scale pond systems (dimensions are in meters).

Figure 2 illustrates an overview of the pilot scale WSP under study after upgrading the existing one with fixed film media and made geometric modifications on the inlets and outlets as well as the installment of passive aerator and vertical wooden baffles.

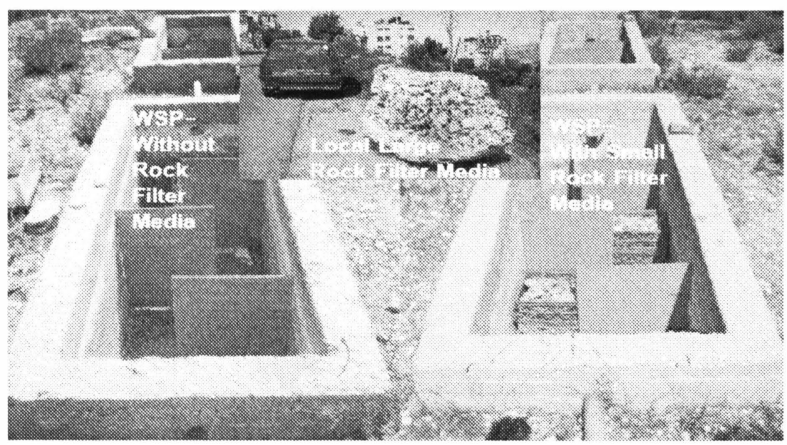

Figure 2. Overview of the upgraded systems (wood-made baffles and biofilter in ARPS)

\subsection{Experimental design and analytical methods}

Both pilot-scale treatment systems were fed with an influent of domestic origin produced at Birzeit University campus, pumped directly from the balancing tank, a preliminary treatment unit of the central biological treatment system. The volumetric loads applied were gradually increased over time by increasing the volume of wastewater flowing into the treatment systems. Two facultative ponds (ARPs) were seeded with activated sludge taken from the mechanized WWTP to initiate the biofilm growth on the rock filters. The inlet pipe was inserted in an inverted $L$ shape tube placed at the left corner of the anaerobic pond to ensure equal distribution of the influent and minimize short circuiting. 
Both treatment systems were continuously fed using a pump installed in the balancing tank at a constant flow rate of $1 \mathrm{~m}^{3} / \mathrm{d}$ to constant level tank, from which each treatment system received a daily flow of $0.5 \mathrm{~m}^{3}$ by a variable speed (two-head) heavy duty peristaltic pump. After the start-up phase, two other experimental phases were performed by applying variable hydraulic loading rates (phase 1 and 2 with $0.7 \mathrm{~m}^{3} / \mathrm{d}$ and $1.0 \mathrm{~m}^{3} / \mathrm{d}$, respectively). The wastewater flow to the remaining ponds was by gravity, while the effluent of polishing ponds (PPs) from both treatment systems was discharged into the slow sand filter well of the mechanized treatment plant. Table 1 summarizes the operational design parameters during the start-up phase for the both treatment systems.

Table 1. Operation design criteria for the start-up phase in both ABPS and ARPS

\begin{tabular}{|c|c|c|c|c|c|}
\hline Description & Unit & Width $(\mathrm{m})$ & $\begin{array}{c}\text { Length } \\
\text { (m) }\end{array}$ & $\begin{array}{c}\text { Depth } \\
\text { (m) }\end{array}$ & $\begin{array}{c}\text { Water } \\
\text { Depth }(\mathrm{m})\end{array}$ \\
\hline Algae-Based Ponds (ABP) 1 & 4 & 1 & 3 & 1 & 0.9 \\
\hline Algae Rock Filter Ponds (ARPI \& ARP2) & 4 & 1 & 3 & 1 & 0.9 \\
\hline \multicolumn{6}{|c|}{ Applied Organic Surface Loading Rate } \\
\hline Optimal design rate & 168 & \multicolumn{2}{|c|}{$\mathrm{kg} \mathrm{COD} / \mathrm{ha} . \mathrm{d}$} & \multicolumn{2}{|c|}{ Optimal design } \\
\hline Organic loading rate & 16.8 & \multicolumn{2}{|c|}{$\mathrm{g} \mathrm{COD} / \mathrm{m}^{2} \cdot \mathrm{d}$} & \multicolumn{2}{|c|}{$<20 \mathrm{~g} \mathrm{COD} / \mathrm{m}^{2} \cdot \mathrm{d}$} \\
\hline Daily flow rate Q (each lain) & 0.5 & \multicolumn{2}{|c|}{$\mathrm{m}^{3} / \mathrm{d}$} & \multicolumn{2}{|c|}{ Start-up Phase } \\
\hline Influent concentration $\mathrm{C}_{1} \mathrm{COD}$ & 775 & \multicolumn{2}{|c|}{$\mathrm{mg} / \mathrm{l}$} & & \\
\hline Daily COD organic loading rate & 0.39 & \multicolumn{2}{|c|}{$\mathrm{kg} \mathrm{COD} / \mathrm{d}$} & & \\
\hline \multicolumn{6}{|c|}{ Operational Design Criteria for Algae-Based Ponds (ABP) and Algae-Rock-filter Ponds (ARP) } \\
\hline Algae-Based Ponds $(A B P s)$ & AnPl & $\mathrm{ABPl}$ & ABP2 & PP1 & Total \\
\hline ABP surface area $\left(\mathrm{m}^{2}\right)$ & 3 & 3 & 3 & 3 & 12 \\
\hline ABP volume $\left(\mathrm{m}^{3}\right)$ & 2.7 & 2.7 & 2.7 & 2.7 & 10.8 \\
\hline Organic loading rate $\left(\mathrm{gCOD} / \mathrm{m}^{2} . \mathrm{d}\right)$ & 129.2 & 30.1 & 15.1 & 7.5 & \\
\hline HRT (d) & 5.4 & 5.4 & 5.4 & 5.4 & 21.6 \\
\hline Algae-Rock Filter Ponds (ARP) & AnPl & ARP1 & ARP2 & PPI & \\
\hline ARP surface area $\left(\mathrm{m}^{2}\right)$ & 3 & 17.4 & 17.4 & 3 & 40.8 \\
\hline ARP volume $\left(\mathrm{m}^{3}\right)$ & 2.7 & 2.86 & 2.86 & 2.7 & 11.12 \\
\hline Organic loading rate $\left(\mathrm{gCOD} / \mathrm{m}^{2} \cdot \mathrm{d}\right)$ & 129.2 & 5.2 & 2.6 & 1.3 & \\
\hline HRT $(\mathrm{d})$ & 5.4 & 5.72 & 5.72 & 5.4 & 22.24 \\
\hline
\end{tabular}

Both systems were monitored between December 2005 and February 2006 (start-up phase) when the hydraulic retention time (HRT) was about 22 days $\left(Q=0.5 \mathrm{~m}^{3} / \mathrm{d}\right)$, and from March to August 2006 during the second $\left(Q=0.7 \mathrm{~m}^{3} / \mathrm{d}\right)$ and third $\left(\mathrm{Q}=1.0 \mathrm{~m}^{3} / \mathrm{d}\right)$ run phases, where HRTs between 15 and 11 days prevailed, respectively. Grab samples from the inlet and outlet of each pond series were taken regularly (HRT based) during the various experimental phases. All samples were assessed for their content in COD, total suspended solids (TSS), dissolved forms of nitrogen and phosphorous and fecal coliform bacteria (FC) following the analytical procedures directed by the Standard Methods [21]. Several other physicochemical and operational parameters corresponding to the operation phases were also measured and are summarized in Table 2. 
Table 2: Physical and chemical analysis of influent feeding the pilot-scale treatment plants

\begin{tabular}{|c|c|c|c|c|c|c|c|}
\hline \multirow{2}{*}{ Parameter } & \multicolumn{5}{|c|}{ Sampling Date } & \multirow{2}{*}{ Average } & \multirow{2}{*}{ SD \pm} \\
\cline { 2 - 7 } & $7 / 12 / 05$ & $12 / 12 / 05$ & $20 / 12 / 05$ & $18 / 1 / 06$ & $13 / 02 / 06$ & & \\
\hline $\mathrm{T}^{\circ} \mathrm{C}(\mathrm{water})$ & 22 & 20 & 18 & 13.8 & 10 & 16.8 & 4.8 \\
\hline $\mathrm{pH}(-)$ & 8.51 & 8.09 & 8.09 & 7.98 & 8.12 & 8.2 & 0.2 \\
\hline $\mathrm{DO}(\mathrm{mg} / \mathrm{l})$ & 2.49 & 2.57 & 2.84 & 5.21 & 4.3 & 3.5 & 1.2 \\
\hline $\mathrm{EC}(\mu \mathrm{s} / \mathrm{cm})$ & 1423 & 1448 & 1598 & 1006 & 1640 & 1423 & 251 \\
\hline $\mathrm{TSS}(\mathrm{mg} / \mathrm{l})$ & 1070 & 1318 & 1380 & 932 & 1290 & 1198 & 189 \\
\hline $\mathrm{COD}(\mathrm{mg} / \mathrm{l})$ & 391 & 822 & 938 & 646 & 1080 & 775 & 268 \\
\hline $\mathrm{BOD}(\mathrm{mg} / \mathrm{l})$ & 318 & 506 & 574 & 396 & 648 & 488 & 133 \\
\hline $\mathrm{NH}_{4}-\mathrm{N}(\mathrm{mg} / \mathrm{l})$ & 64.1 & 82.0 & 93.8 & 33.3 & 65.4 & 67.7 & 22.9 \\
\hline $\mathrm{PO}_{4}-\mathrm{P}(\mathrm{mg} / \mathrm{l})$ & 5.5 & 4.5 & 8.4 & 3.2 & 6.5 & 5.6 & 2.0 \\
\hline FC $\left(\mathrm{Log}_{10} \mathrm{CFU} / 100 \mathrm{ml}\right)$ & 8.02 & 8.18 & 8.08 & 8.42 & 6.56 & 7.87 & 6.20 \\
\hline
\end{tabular}

\section{RESULTS AND DISCUSSION}

\subsection{Operation and Performance Evaluation}

During the first experimental run (start-up phase), both systems reached a steady state process, where grab samples of the final effluent from ABPs and ARPs revealed an average COD value of 140 and $75 \mathrm{mg} / \mathrm{L}$, respectively. However, due to low temperature $\left(12{ }^{\circ} \mathrm{C}\right)$ during the cold winter season (January-February 2006), the start up phase took almost one month for the Rock Filter Ponds to establish a healthy biofilm. This was confirmed through microscopic trials (Fig. 3a and b) made using a phase contrast microscope by well established biozenosa of algae, protozoa and bacterial flocs on the rock filter media.

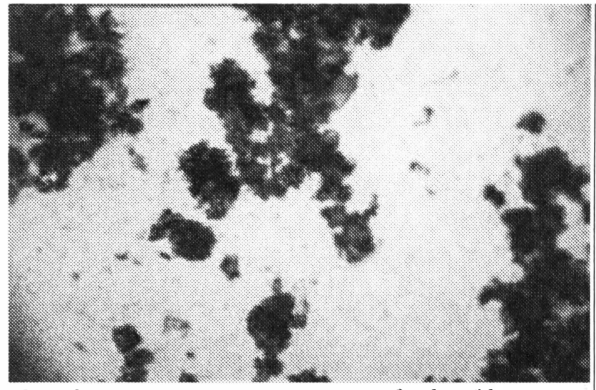

Fig. 3a. Microscopic picture of a biofilm from ARPs system (Gram stain picture: $x / 000)$

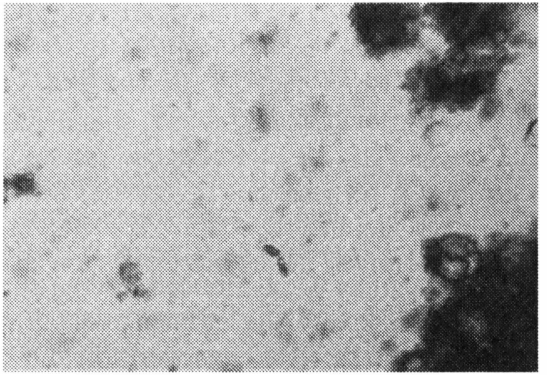

Fig 3b. Compact algal-biofilm biozenosa (Free swimming bacteria, protozoa and algae; $x$ 1000)

During the start-up phase, the mean values for all parameters measured in the grab samples of influent and pond effluents in both experiments are presented in Table 2. Despite wide fluctuations in the influent, both treatment systems reached steady state conditions as to effluent quality. The mean pond influent temperatures averaged $16.8^{\circ} \mathrm{C}$ throughout the startup phase, $23.5^{\circ} \mathrm{C}$ in the second experimental period and $27.8^{\circ} \mathrm{C}$ in the third. In both periods 
the $\mathrm{pH}$ decreased slightly from the raw sewage to the anacrobic pond effluent and then gradually increased along the series, reaching mean values in the final effluent of 7.86 and 7.97 in the effluent of ARPs and ABPs system, respectively. In ARPs the DO concentration was $1.88 \mathrm{mg} / \mathrm{l}$ in the readings taken from $0.15 \mathrm{~m}$ below pond surface, $1.66 \mathrm{mg} / \mathrm{L}$ in the effluent from the WSPs control. The higher values in the ARPs effluent were due to higher microbial activity occurring in the facultative ponds. The WSPs effluent contained less DO than the facultative pond effluent of the ARPs throughout all run phases.

During second experimental run (HRT $11 \mathrm{~d}$ ), COD and TSS removals were much higher in the passive aerated algae-rock filter than in the WSPs. The mean COD and SS removals were $87.5 \%$ and $87.3 \%$, respectively, in the ARPs, compared to $81.7 \%$ and $78.6 \%$ in the ABPs control (Fig. 4 and 5).

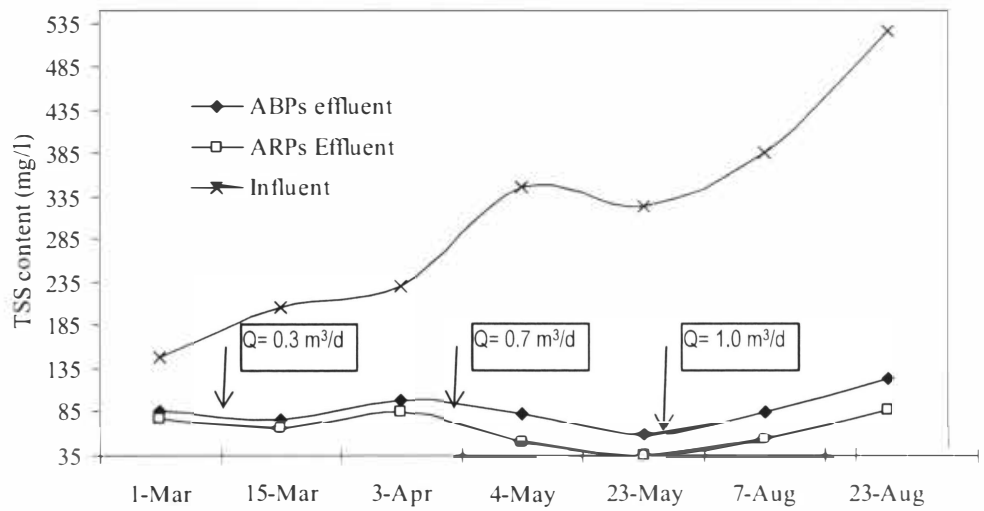

Figure 4. Influent and effluent TSS of ABPs and ARPs during the three run phases

The average effluent COD concentrations were $85 \mathrm{mg} / \mathrm{l}$ in the passive aerated filter and 125 $\mathrm{mg} / \mathrm{l}$ in the WSPs control; the corresponding figures for the TSS were 42 and $71 \mathrm{mg} / \mathrm{l}$. The effluent TSS content in both systems is predominantly of algal origin, since the majority of the non-algal solids were removed in the facultative ponds. The effluents from both systems therefore comply with the effluent requirements of $<\_20 \mathrm{mg} / \mathrm{l}$ BOD and $<$ 30 $\mathrm{mg} / \mathrm{l} \mathrm{TSS}$ commonly set for small sewage works by the Palestinian Standards Institution [20].

The results of our initial work during the first run phase (March-April 2006) on both treatment systems revealed that the daily hydraulic loading rate of $0.19 \mathrm{~m}^{3} / \mathrm{m}^{3}$ had shown no major differences on facultative pond effluents of ARPs and ABPs. Both systems maintained a stable effluent quality at an increased daily HLR of $\theta .26 \mathrm{~m} 3 / \mathrm{m} 3$ per at the beginning of May 2006.

However, ABPs Similar results were reported by Johnson and Mara [15] for BOD and SS removals were much higher in the aerated filter than in the un-aerated filter, where the 95 percentile effluent COD concentrations were $54 \mathrm{mg} / \mathrm{Lan}$ the aerated filter and $190 \mathrm{mg} / \mathrm{L}$ in the un-aerated control, and the corresponding figures for TSS were 25 and $60 \mathrm{mg} / \mathrm{L}$. These data 
confirmed the early results reported by Saidam et al.. [12] on upgrading WSPs effluent using a pilot-scale rock filter ponds (un-aerated) after the polishing ponds at As Samra waste stabilization ponds, where effluent TSS was around $100 \mathrm{mg} / \mathrm{l}$. The limiting factor was the volumetric loading rate $\left(0.27-0.5 \mathrm{~m}^{3} / \mathrm{m}^{3}\right.$.d) applied by Saidam et al., [12], while Johnson and Mara [15] found that $0.15-\left(0.3 \mathrm{~m}^{3} / \mathrm{m}^{3}\right.$.d was the optimal rage for achieving effluent quality requirements commonly set for small wastewater treatment plants by the Environment Agency for England and Wales.

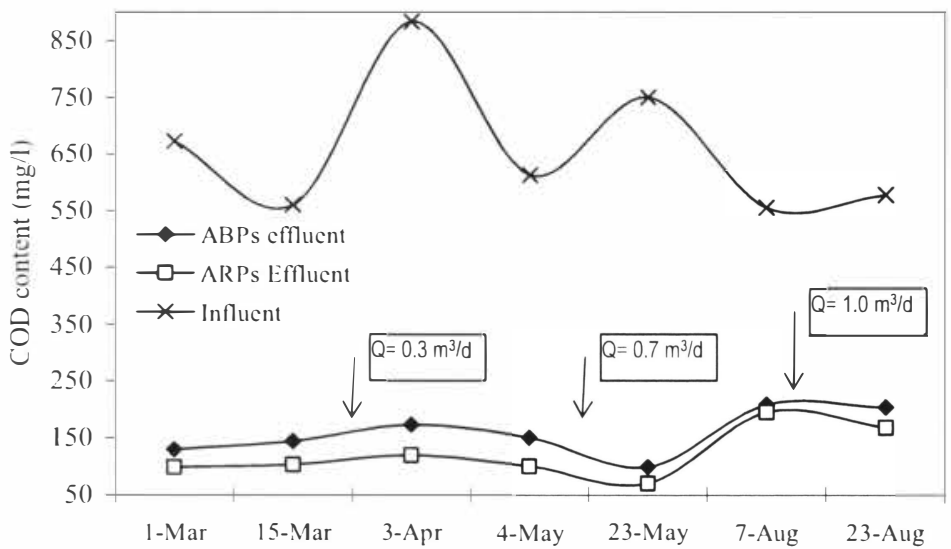

Figure 5. Influent COD. ABPs and ARPs effluent quality during the three run phases

According to the experimental data obtained during the third run phase (Fig. 5), doubling the HLR (from 0.20 to $0.40 \mathrm{~m}^{3} / \mathrm{m}^{3}$.d) has reduced the COD removal efficacy in the ABPs $(64 \%$ ) much more than the ARPs $(73 \%)$, this might be due to lower surface organic loading rate exerted by the rock-filter installed in the facultative ponds. The results indicate that ARPs can tolerate higher surface organic loading rates (i.e. HLRs) and produced a COD effluent of 150 $\mathrm{mg} / \mathrm{l}$ compared with $208 \mathrm{mg} / \mathrm{l}$ for the ABPs. The TSS removal in both systems showed similar tendencies at higher HLR. To this end, ABPs can only achieve similar effluent quality as the ARPs only through additional installment of land area, implying extra financial investment compared to land saving algae-rock filter ponds.

Irrespective of the population served by the individual pilot-scale systems, the total surface area available within the ARPs was $40 \mathrm{~m}^{2}$ compared to ABPs with only $12 \mathrm{~m}^{2}$, leading to a factor of 3.3 folds in capital investment for land area, when considering the conventional WSPs without rock-filter media. This can be best illustrated by taking operational conditions during the second run phase, where each of the systems served about 4 capita. The difference in COD surface loading rates applied during this run phase on ARPs and ABPs was 12 and 40 g COD $/ \mathrm{m}^{2}$.d, respectively, implying a ratio of 3.3 for ABPs to achieve the same effluent quality produced by the ARPs. Due to space limitation, detailed data obtained on ammonium removal rates are not shown here, however ARPs were better (68.2\%) compared to ABPs with only $56.7 \%$. Higher nitrification rates within the ARPs might be due to high surface area available for the nitrifiers and less organic loading rates. 
Average concentrations for fecal coliforms (FC) as indicator bacteria are presented in Figure 6 for the ABPs and ARPs treatment systems. Using the influent to the anaerobic ponds as the starting point, individual system component per cent removals were calculated to determine the cumulative removal by each system. During the second run phase, the ARPs system showed an overall removal of $99.96 \%$ of fecal coliforms compared with $99.92 \%$ for the ABPs. During the second phase, ARPs showed higher removal rates $(77 \%)$ in FC content between the inflow of facultative ponds and the polishing ponds effluent. While the cumulative system reduction for FC was only $69.1 \%$ in the ARPs system during the same run phase. Previous studies [22-23] indicated that the FC removal in may be attributed primarily to removal in the anaerobic ponds as a result of cell die-off and settling of the materials, degradation of organic matter, and competition of microorganisms for limiting nutrients or trace elements, and membrane desiccation. In the ARPs system, filtration, adsorption, aggregate formation, and predators due to passive aerobic conditions and rock-filter media surface area may favored the higher FC removal rates observed.

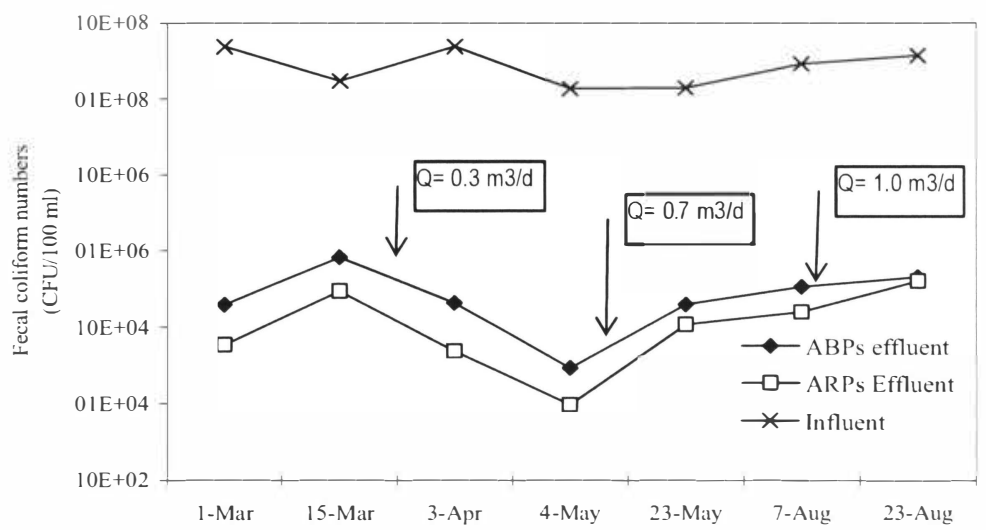

Figure 6. Fecal coliform counts (colony forming units/100 ml) in algae-based ponds and algae-rock filter system

Based on fecal coliforms, the PSI [20] sets three quality categories within the Palestinian guidelines on wastewater disposal and reuse; category A for high quality (less than 200 $\mathrm{CFU} / 100 \mathrm{ml}$ ) and $\mathrm{B}$ to $\mathrm{D}$ for good (less than $1000 \mathrm{CFU} / 100 \mathrm{ml}$ ) to bad effluent quality. The results shown in Fig. 6 indicate that the treated effluent from both treatment systems did not comply neither with the PSI nor the WHO effluent requirements for unrestricted irrigation. However, this might be improved by installing tertiary treatment units as disinfection systems and rock-filters at the polishing ponds exits [24-25].

\section{CONCLUSIONS AND RECOMMENDATIONS}

Production of effluent with good quality suitable for agriculture irrigation is achievable using natural treatment systems, if the treatment plant is well designed and adequately operated. Algae-rock filter ponds (ARPs) with natural fixed film media (Kharram stones) as microbial 
support materials, is an innovative system revealed higher treatment efficiency than conventional waste stabilization ponds. Compared to current onsite treatment plants in Palestine, the developed system has many benefits; easy to construct, install and operate, lowcost, durable media lasting for many years. The ARPs can be recommended for individual households, cluster of households or even for decentralized treatment system for small communities. This study can be replicated and scaled-up in other Palestinian rural areas, as well as in other parts of the Mediterranean zone.

Although some progress has been made in understanding the processes that operate in the algal-biofilm layer there is still a lot to be learned before adequate process design and control models can be developed. It is obvious that the algal-biofilm ponds can operate effiectively i.e. produce an effluent with total inorganic-N levels of less than $20 \mathrm{mg} / \mathrm{L}$, a COD less than 100 $\mathrm{mg} / \mathrm{L}$ and low levels of TSS. However, more information is required as to the efficiency of the developed system for nutrient removal. What is the best pre-treatment technology for the removal of COD? How can we enhance the removal of microbial pathogens in algal-biofilm ponds? Is there a need for internal recirculation and what possible impacts would this have on the nitrification-denitrification processes? What are the possible effiects of exerting high hydraulic loads on the washout of algal-biofilm? These questions can only be answered by further research studies, where ongoing research will partially provide answers on some of the raised questions above.

\section{ACKNOWLEDGMENTS}

This study, a joint research led by the Institute of Environmental and Water Studies at Birzeit University and other two local partners, was executed through the financial support from the UNESCO-Flanders Program, for which the authors gratefully acknowledge. Partial funding for the publication of this research was received from Kalmar University, Sweden.

\section{REFERENCES}

1. Al-Sa ed, R. (2007). Pathogens assessment in reclaimed effluent used for industrial crops irrigation. Intl. .J. En'. Res. Public Health (IJERPH), 4(1), 68-75.

2. Al-Sa ed, R. and Mubarak, S. (2006). Sustainability assessment of onsite sanitation facilities in Ramallah-Albireh district with emphasis on technical, socio-cultural and financial aspects. Manag. Environ. Quality: An International Journal, 17(2), 140-156.

3. Tchobanoglous, G. and Angelakis, A.N. (1996). Technologies for wastewater treatment appropriate for reuse: Potential for applications in Greece. Wat. Sci. Tech., 33(10-11), 15-24.

4. Mara, D.D. and Pearson, H. (1998). Design Mamual for Waste Stabilization Ponds in Mediterranean Countries. Lagoon Technology International Ltd., Leeds, UK.

5. Mara, D.D. (2000). The production of microbiologically safe effluents for wastewater reuse in the Middle East and North Africa. Wat. Air Soil Poll., 123(1-4), 595-603.

6. Zimmo, O.R., Al-Sa'ed, R.M. and Gijzen, H. (2000). Comparison between algaebased and duckweed-based wastewater treatment: differences in environmental conditions and nitrogen transformations. Wat. Sci. and Tech., 42(10/11), 215-222

7. Kima, Y., Giokasb, D.L., Lee, J.-W. and Paraskevasd, P.A. (2006). Potential of natural treatment systems for the reclamation of domestic sewage in irrigated agriculture. Desalination, 189, 229-242. 
8. Shin, H.K. and Polprasert, C. (1988). Ammonia nitrogen removal in attached-growth Ponds. J. Environ. Engng., 114, 846-863.

9. Polprasert, C. and Charnpratheep, K. (1989). Heavy metal removal in attached-growth waste stabilization ponds. Wat. Res., 23, 625-631.

10. Qi, P.S., Wang, B.Z., Ma, F., Zhang, J.S. and Li, T.J. (1993). Intensification of a pond by fibrous carriers. Wat. Sci. Tech. 28(7), 117-123.

11. Smith, D.W. (1993). Wastewater treatment with complementary filter feeders - a new method to control excessive suspended solids and nutrients in stabilization ponds. W'at. Environ. Res.e 65(5), 650-654.

12. Saidam, M.Y., Ramadan, S.A. and Butler, D. (1995). Upgrading waste stabilization pond effluent by rock filters. Wat. Sci. Tech., 31(12), 369-378.

13. Zhao, Q.L. and Wang, B.Z. (1996). Evaluation on a pilot-scale attached-growth pond system treating domestic wastewater. Wat. Res., 30(1), 242-245.

14. Shilton, A., Pratt, S., Drizo, A., Mahmood, B., Banker, S., Billings, L., Glenny, S. and Luo, D. (2005). Active filters for upgrading phosphorus removal from pond systems. Wat. Sci. Tech., 51 (12), 111-116.

15. Johnson, M. and Mara, D.D. (2005). Aerated rock filters for enhanced nitrogen and faecal coliform removal from facultative waste stabilization pond effluents. Wat. Sci. Tech., 51(12), 99-102.

16. Barjenbruch, M. and Erler, C. (2005). A performance review of small German WSPs identifying improvement options. Wat. Sci.Tech., 51(12), 43-49.

17. ATV-DVWKArbeitsblatt A 201 (2004). Grundsätze fïr die Bemessung, Bau und Betrieb von Abwasserteichen für kommunales Abwasser, Gesellschaft zur Foerderung der Abwassertechnik e.V., Hennef, Germany.

18. PWA, Palestinian Water Authority. (2007). Annual Monitoring Reports on Surface water and Groundwater Wells, Water Resources Department, Personal communication.

19. WHO, World Health Organization. (2006). Health Guidelines for the Use of Wastewater in Agriculture and Aquaculture. Report of the WHO Scientific Group, Geneva, Switzerland.

20. PSI, Palestine Standards Institution. (2003). Guidelines for treated wastewatere Disposal and reuse, Final Draft (Arabic version No. 2). PSI, Ramallah, West Bank, Palestine, 2003.

21. APHA, American Public Health Association. (1998). Standard Methods for the Examination of Water and Wastewater, $20^{\text {th }}$ Ed., APHA, Washington, DC., USA.

22. El-Hamouri, B., Handouf, A., Mekrane, M., Touzani, M. (1996). Use of wastewater for crop production under arid and saline conditions: yield and hygienic quality of the crop and soil contamination. Wat. Sci. Tech., 33, 327-334.

23. Rangeby, M., Johansson, P. and Pernrup, M. (1996). Removal of coliforms in wastewater stabilization ponds system in Midelo. Wat. Sci. Tech., 34, 149-157.

24. Jagals, D. and Lues, J.F.R. (1996). The efficiency of a combined waste stabilization pond-maturation pond system to sanitize wastewater intended for recreational reuse. Wat. Sci. Tech., 33, 117-124.

25. Government of Jordan. (2003). Technical Regulation for Reclaimed Domestic Wastewater. JS893/2002, Jordan Institution for Standards and Meteorology, Jordan. 